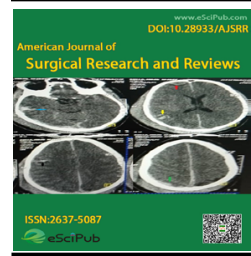

American Journal of Surgical Research and Reviews (ISSN:2637-5087)

\title{
Comparative Study Of Open Cholecystectomy In Acute And Chronic Cholelithiasis In Rural Centre Of India.
}

\section{Dr. Jitendra Kumar Saroj', Dr. Santosh Gautam², Dr Ganesh Chandra yadav ${ }^{3}$}

${ }^{1}$ Assistant Professor, Department Of General Surgery, Venkteshwara Institute Of Medical Sciences, Gajraula, India; ${ }^{2}$ Assistant professor, Prasad institute of medical science,Junab Ganj,UP-226401; ${ }^{3}$ Assistant professor, Dept of general surgery,Maa vindhyavasini autonomous state medical college Mirzapur uttarpradesh

\section{ABSTRACT}

The incidence of cholecystitis with cholelithiasis is increasing day by day either acute or chronic cases. Gall stones are the most common cause of acute cholecystitis in $90-95 \%$ of the cases. The management of acute cholecystitis is still laparoscopic cholecystectomy in urban area of India but in rural area open cholecystectomy is still preferred method of surgery for acute as well as chronic gall stone. Our study was conducted on 100 patients divided into two groups of 50 of each to compare the results of open cholecystectomy between acute and chronic cases. The overall post-operative morbidity was more in acute cases. But there was significant difference in the total hospital stay and total cost of the therapy in both the groups. drain output was also high in first three days in acute case so, acute case cholecystectomy was found to be more expensive overall and higher length stay and more co morbidities than chronic cases.
${ }^{*}$ Correspondence to Author:

Dr. Jitendra Kumar Saroj

Assistant Professor, Department Of General Surgery, Venkteshwara Institute Of Medical Sciences, Gajraula, India

How to cite this article:

Jitendra Kumar Saroj, Santosh Gautam, Ganesh Chandra yadav. Comparative Study Of Open Cholecystectomy In Acute And Chronic Cholelithiasis In Rural Centre Of India. .American Journal of Surgical Research and Reviews, 2021, 4:36.

\section{eScîPub}

eSciPub LLC, Houston, TX USA. Website: https://escipub.com/ By using the site/services, you are agreeing to our Policies: https:// escipub.com/terms-privacy-policydisclaimer/ 


\section{Introduction}

Gall stone is a common disease worldwide. Now a day's incidence is increasing rapidly. Especially reproductive age females are more prone to this disease [1]. Carl Langenbuch performed the first successful open cholecystectomy in 15 July $1882{ }^{\text {[2]. In } 1987}$ Philippe Mouret of France first introduced Laparoscopic cholecystectomy and which quickly revolutionized the treatment of gall stone [3]. Now in this developing era cholecystectomy can be performed by open and minimal invasive surgery like as laparoscopic and robotic methods. Now, laparoscopic cholecystectomy is the current gold standard treatment for gall stone diseases [4]. laparoscopic approach reduced hospitalization decreased cost, reduced pain, better cosmetics, reduced recovery time and early return to work ${ }^{[5]}$.in developing country still open cholecystectomy is considered gold standard treatment and controversies remains exist ${ }^{[6]}$.even showing early promising results increase incidence of operative complications, especially cbd injury [7]

\section{Method}

A prospective study of open cholecystectomy between acute and chronic cholecystitis was performed from 25 July 2020 to 26 July 2021 in surgery department of navjeevan hospital kashipur uttrakhand

\section{AIMS AND OBJECTIVE}

To compare safety and clinical efficacy in acute and chronic gall stone disease after open cholecystectomy in terms of cost, hospital stay, bile leak, operative times and pain at discharge.

\section{Inclusion criteria}

Symptomatic gall bladder

Clinical; Tender right hypochondrium, lump may be palpable, Murphy sign positive

Radiological; edematous, distended gall bladder with stone or sludge

Acute cholecystitis ( $<10$ days)

Chronic cholecystitis ( $>4$ weeks)

Mucocoele, wall thickening
WBC Cells $>11000$ cell/cumm $<16000$

\section{Exclusion criteria}

No diabetes

No hypertension

CBDstone, pancreatitis, perforated gall bladder WBC $>16000$ cell/cumm

\section{Operative history}

Open cholecystectomy was performed in both acute and chronic cases. Same paramedian incision was given. In acute case incision was extended in 4 cases due to omental adhesion over gall bladder with liver due to mucocoele. While in chronic case incision was extended in 3 cases because of chronic contracted gall bladder to avoid injury to common bile duct. Abdominal drain k-90 was placed in all cases even if there is no bleeding as routinely

\section{Follow up}

First follow -up after 10 days then after 2 weeks 3 weeks and 6 weeks

\section{Statistical analysis:}

The data collected was entered in the computer database. The statistical analysis was done using SPSS (Statistical Package for Social Sciences) Version 16.0. Quantitative study variables were described in frequency, percentage, mean and standard deviation. Quantitative study variables were converted into categorical groups and data were analyzed by chi square test. The $p$-value was determined finally to evaluate the levels of significance. The $p$-value of $>0.05$ was considered non significant; $p$-value of 0.01 to 0.05 was considered significant.

\section{Result and interpretation:}

Open cholecystectomy was done in all 100 cases divided into two groups of 50 of each to compare the results of open cholecystectomy between acute and chronic cases in terms of cost, hospital stay, bile leak, operative times and pain at discharge.

Table 1 illustrates that descriptive statistics of quantitative study variables in both groups acute 
and chronic cholecystitis. Mean age of cases in acute cholecystitis were 40.18 years and chronic cholecystitis 39.8 years. Age range of cases in both group were almost equal. Operative time intended for cases belong to acute cholecystitis was higher as compared to chronic cholecystitis cases. Mostly, average days for drain removal and hospital stay were more in acute cholecystitis cases. Total average operative cost for acute cholecystitis cases was more than chronic cases.

Table 1: Mean and standard deviation of quantitative study variables in both groups acute and chronic cholecystitis.

\begin{tabular}{|l|l|l|l|l|l|l|}
\hline Groups & Variables & $\begin{array}{l}\text { Age } \\
\text { (in years) }\end{array}$ & $\begin{array}{l}\text { Operative } \\
\text { Time(in } \\
\text { Minutes) }\end{array}$ & $\begin{array}{l}\text { Drain } \\
\text { removal } \\
\text { days) }\end{array}$ & $\begin{array}{l}\text { Hospital } \\
\text { stay } \\
\text { days) }\end{array}$ & $\begin{array}{l}\text { Operative } \\
\text { Cost } \\
\text { Rupees) }\end{array}$ \\
\hline \multirow{3}{*}{$\begin{array}{l}\text { Acute } \\
\text { cholecystitis } \\
\text { cases (n=50) }\end{array}$} & Mean & 40.18 & 41.44 & 3.44 & 4.66 & 12240 \\
\cline { 2 - 7 } & $\begin{array}{l}\text { Standard } \\
\text { deviation }\end{array}$ & 13.85 & 10.05 & 0.78 & 0.71 & 1543.50 \\
\cline { 2 - 7 } & Minimum value & 21 & 20 & 3 & 3 & 10000 \\
\cline { 2 - 7 } & $\begin{array}{l}\text { Maximum } \\
\text { value }\end{array}$ & 80 & 60 & 6 & 6 & 15000 \\
\hline \multirow{2}{*}{$\begin{array}{l}\text { Chronic } \\
\text { cholecystitis } \\
\text { cases (n=50) }\end{array}$} & Mean & 39.80 & 40.14 & 3.12 & 4.00 & 10591.84 \\
\cline { 2 - 7 } & $\begin{array}{l}\text { Standard } \\
\text { deviation }\end{array}$ & 11.70 & 11.43 & 0.39 & 0.61 & 924.02 \\
\cline { 2 - 8 } & Minimum value & 18 & 25 & 3 & 3 & 10000 \\
\cline { 2 - 7 } & $\begin{array}{l}\text { Maximum } \\
\text { value }\end{array}$ & 74 & 75 & 5 & 5 & 14000 \\
\hline
\end{tabular}

Table 2: Age group wise distribution of cases in both groups acute and chronic cholecystitis.

\begin{tabular}{|c|c|c|c|c|c|}
\hline \multirow{2}{*}{\multicolumn{2}{|c|}{ Age groups }} & \multicolumn{2}{|c|}{ Cholecystitis cases } & \multirow[t]{2}{*}{ Total } & \multirow{2}{*}{$\begin{array}{l}\text { Chi Square, } \\
\text { P value }\end{array}$} \\
\hline & & Acute & Chronic & & \\
\hline \multirow[t]{2}{*}{$\leq 30$} & $\mathbf{n}$ & 17 & 14 & 31 & \multirow{10}{*}{$\begin{array}{l}4.415, \\
0.353\end{array}$} \\
\hline & $\%$ & $54.8 \%$ & $45.2 \%$ & $100.0 \%$ & \\
\hline \multirow[t]{2}{*}{$31-40$} & $n$ & 11 & 13 & 24 & \\
\hline & $\%$ & $45.8 \%$ & $54.2 \%$ & $100.0 \%$ & \\
\hline \multirow[t]{2}{*}{$41-50$} & $n$ & 10 & 17 & 27 & \\
\hline & $\%$ & $37.0 \%$ & $63.0 \%$ & $100.0 \%$ & \\
\hline \multirow[t]{2}{*}{$51-60$} & $n$ & 9 & 5 & 14 & \\
\hline & $\%$ & $64.3 \%$ & $35.7 \%$ & $100.0 \%$ & \\
\hline \multirow[t]{2}{*}{$>60$} & $\mathbf{n}$ & 3 & 1 & 4 & \\
\hline & $\%$ & $75.0 \%$ & $25.0 \%$ & $100.0 \%$ & \\
\hline
\end{tabular}

Table 2 depicts that the age group wise distribution of cases in acute and chronic cholecystitis. In which, mean age in acute cholecystitis was $40.18 \pm 13.85$ and chronic cholecystitis was $39.80 \pm 11.70$. Majority of cases were below fifty years in both the group. Out of which 31 cases were belongs to younger age less than 30 years. Almost equal percent of cases in both groups. Only 4 cases were above 60 years. Among them 3 cases was acute cholecystitis. Statistical differences between age group \& acute and chronic cholecystitis were statistically not significant $(p>0.05)$

Table 3 gender wise distribution of cases in acute and chronic cholecystitis. In which, female predominance is present in both the groups. Statistical differences between gender \& acute and chronic cholecystitis were statistically not significant $(p>0.05)$ 
Table 3: Gender wise distribution of cases in both groups acute and chronic cholecystitis.

\begin{tabular}{|c|c|c|c|c|c|}
\hline \multirow{2}{*}{\multicolumn{2}{|c|}{ Gender }} & \multicolumn{2}{|c|}{ Cholecystitis cases } & \multirow[t]{2}{*}{ Total } & \multirow{2}{*}{$\begin{array}{l}\text { Chi Square, } \\
\text { P value }\end{array}$} \\
\hline & & Acute & Chronic & & \\
\hline \multirow{2}{*}{ Female } & $n$ & 41 & 41 & 82 & \multirow{4}{*}{$\begin{array}{l}0.00 \\
1.00\end{array}$} \\
\hline & $\%$ & $50.0 \%$ & $50.0 \%$ & $100.0 \%$ & \\
\hline \multirow[t]{2}{*}{ Male } & $\mathbf{n}$ & 9 & 9 & 18 & \\
\hline & $\%$ & $50.0 \%$ & $50.0 \%$ & $100.0 \%$ & \\
\hline
\end{tabular}

Table 4: Univariate analysis of categorical study variables with respect to cases in both groups acute and chronic cholecystitis.

\begin{tabular}{|c|c|c|c|c|c|c|}
\hline \multirow{2}{*}{\multicolumn{3}{|c|}{ Study variable }} & \multicolumn{2}{|c|}{ Cholecystitis cases } & \multirow{3}{*}{$\begin{array}{l}\text { Total } \\
49 \\
\end{array}$} & \multirow{2}{*}{$\begin{array}{l}\text { Chi Square, } \\
\text { P value }\end{array}$} \\
\hline & & & Acute & Chronic & & \\
\hline \multirow{6}{*}{$\begin{array}{l}\text { Operative time } \\
\text { (in minutes) }\end{array}$} & \multirow[t]{2}{*}{ 20- 40} & $\mathbf{n}$ & 19 & 30 & & \multirow{6}{*}{$\begin{array}{l}7.91 \\
0.02\end{array}$} \\
\hline & & $\%$ & 38.8 & 61.2 & 100.0 & \\
\hline & \multirow[t]{2}{*}{$40-60$} & $n$ & 31 & 18 & 49 & \\
\hline & & $\%$ & 63.3 & 36.7 & 100.0 & \\
\hline & \multirow[t]{2}{*}{$60-80$} & $n$ & 0 & 2 & 2 & \\
\hline & & $\%$ & 0.0 & 100.0 & 100.0 & \\
\hline \multirow{8}{*}{$\begin{array}{l}\text { Drain removal } \\
\text { (in days) }\end{array}$} & \multirow[t]{2}{*}{ 3rd } & $n$ & 35 & 45 & 80 & \multirow{8}{*}{$\begin{array}{l}6.82 \\
0.07\end{array}$} \\
\hline & & $\%$ & 43.8 & 56.2 & 100.0 & \\
\hline & \multirow[t]{2}{*}{ 4th } & $n$ & 10 & 4 & 14 & \\
\hline & & $\%$ & 71.4 & 28.6 & 100.0 & \\
\hline & \multirow[t]{2}{*}{ 5th } & $\mathrm{n}$ & 3 & 1 & 4 & \\
\hline & & $\%$ & 75.0 & 25.0 & 100.0 & \\
\hline & \multirow{2}{*}{$\begin{array}{l}\text { After 5th } \\
\text { day }\end{array}$} & $n$ & 2 & 0 & 2 & \\
\hline & & $\%$ & 100.0 & 0.0 & 100.0 & \\
\hline \multirow{8}{*}{$\begin{array}{l}\text { Hospital stays } \\
\text { (in days) }\end{array}$} & \multirow[t]{2}{*}{ 3rd } & $n$ & 3 & 9 & 12 & \multirow{8}{*}{$\begin{array}{l}22.90 \\
0.00\end{array}$} \\
\hline & & $\%$ & 25.0 & 75.0 & 100.0 & \\
\hline & \multirow[t]{2}{*}{ 4th } & $n$ & 15 & 32 & 47 & \\
\hline & & $\%$ & 31.9 & 68.1 & 100.0 & \\
\hline & \multirow[t]{2}{*}{ 5th } & $n$ & 28 & 9 & 37 & \\
\hline & & $\%$ & 75.7 & 24.3 & 100.0 & \\
\hline & \multirow{2}{*}{$\begin{array}{l}\text { After 5th } \\
\text { day }\end{array}$} & $n$ & 4 & 0 & 4 & \\
\hline & & $\%$ & 100.0 & 0.0 & 100.0 & \\
\hline \multirow[t]{8}{*}{ Pain at discharge } & \multirow[t]{2}{*}{ No pain (0) } & $n$ & 10 & 35 & 45 & \multirow{8}{*}{$\begin{array}{l}25.25 \\
0.00\end{array}$} \\
\hline & & $\%$ & 22.2 & 77.8 & 100.0 & \\
\hline & \multirow{4}{*}{$\begin{array}{l}\text { Mild } \\
(1-3) \\
\text { Moderate (4- } \\
7)\end{array}$} & $n$ & 35 & 13 & 48 & \\
\hline & & $\%$ & 72.9 & 27.1 & 100.0 & \\
\hline & & $\mathbf{n}$ & 5 & 2 & 7 & \\
\hline & & $\%$ & 71.4 & 28.6 & 100.0 & \\
\hline & \multirow{2}{*}{$\begin{array}{l}\text { Severe (8- } \\
10)\end{array}$} & $n$ & 0 & 0 & 0 & \\
\hline & & $\%$ & 0.0 & 0.0 & 0.0 & \\
\hline \multirow[t]{4}{*}{ Operative cost (in rupees) } & \multirow[t]{2}{*}{$\leq 11000$} & $n$ & 15 & 40 & 55 & 23.27, \\
\hline & & $\%$ & 27.3 & 72.7 & 100.0 & 0.00 \\
\hline & $>11000$ & $\mathbf{n}$ & 35 & 10 & 45 & \\
\hline & & $\%$ & 77.8 & 22.2 & 100.0 & \\
\hline
\end{tabular}

Table 4 reveals the distribution of cholecystitis cases among the study variable according to acute and chronic. Forty-nine cases carried out 20 to 40 minutes operative time. In which $61.2 \%$ were belongs to chronic cholecystitis cases. In contrast, operative time for majority of acute cholecystitis cases about $61.2 \%$ was 40 to 60 minutes. Difference among operative time \& acute and chronic cholecystitis were found statistically significant $(P<0.05)$. Drain removal of most of acute and chronic cholecystitis cases in third days from operation. The differences among them were not found statistically significant $(P>0.05)$. Majority of cases had 4 days hospital stay.out of which about $68 \%$ cases belong to chronic cholecystitis. While 37 cases 
were discharged on $5^{\text {th }}$ day. Out of which about $75 \%$ cases were belongs to acute cholecystitis. The differences among them were found statistically significant $(P<0.05)$. Not any single cases had severe pain, 55 cases had mild and moderate pain at time of discharge. Percentage of acute cholecystitis cases were higher, who had some sort of pain at the time of discharge. The differences among them were found statistically significant $(P<0.05)$. Total 35 out of 50 acute cholecystitis cases endure more than eleven thousand rupees operative cost. The differences among them were found statistically significant $(P<0.05)$

Table 5: Comparison between Intra operative and post operative complications in cases with respect to acute and chronic cholecystitis.

\begin{tabular}{|c|c|c|c|c|c|c|}
\hline \multirow{2}{*}{\multicolumn{3}{|c|}{ Complications }} & \multicolumn{2}{|c|}{ Cholecystitis cases } & \multirow[b]{2}{*}{ Total } & \multirow{2}{*}{$\begin{array}{l}\text { Chi } \\
\text { Square, } \\
\text { P value }\end{array}$} \\
\hline & & & Acute & Chronic & & \\
\hline \multirow{10}{*}{$\begin{array}{l}\text { Intra } \\
\text { operative }\end{array}$} & \multirow[t]{2}{*}{ Intrahepatic gall bladder } & $\mathbf{n}$ & 3 & 5 & 8 & \multirow{10}{*}{$\begin{array}{l}0.50 \\
0.47\end{array}$} \\
\hline & & $\%$ & 37.5 & 62.5 & 100.0 & \\
\hline & \multirow[t]{2}{*}{ Cholecystodudenal fistula } & $\mathbf{n}$ & 0 & 2 & 2 & \\
\hline & & $\%$ & 0.0 & 100.0 & 100.0 & \\
\hline & \multirow[t]{2}{*}{ Mucocoele } & $n$ & 13 & 3 & 16 & \\
\hline & & $\%$ & 81.3 & 18.7 & 100.0 & \\
\hline & \multirow[t]{2}{*}{ Pericholecystic fluid collection } & $\mathbf{n}$ & 0 & 0 & 0 & \\
\hline & & $\%$ & 0.0 & 0.0 & 0.0 & \\
\hline & \multirow[t]{2}{*}{ Perforated gall bladder } & $\mathbf{n}$ & 0 & 0 & 0 & \\
\hline & & $\%$ & 0.0 & 0.0 & 0.0 & \\
\hline \multirow{12}{*}{$\begin{array}{l}\text { Post- } \\
\text { operative }\end{array}$} & \multirow[t]{2}{*}{ Bile leak } & $\mathbf{n}$ & 2 & 0 & 2 & \multirow{12}{*}{$\begin{array}{l}0.65 \\
0.42\end{array}$} \\
\hline & & $\%$ & 100.0 & 0.0 & 100.0 & \\
\hline & \multirow[t]{2}{*}{ Skin infection } & n & 7 & 4 & 11 & \\
\hline & & $\%$ & 63.6 & 36.4 & 100.0 & \\
\hline & \multirow[t]{2}{*}{ CBD injury } & $\mathbf{n}$ & 0 & 0 & 0 & \\
\hline & & $\%$ & 0.0 & 0.0 & 0.0 & \\
\hline & \multirow[t]{2}{*}{ Bowel injury } & n & 0 & 0 & 0 & \\
\hline & & $\%$ & 0.0 & 0.0 & 0.0 & \\
\hline & \multirow[t]{2}{*}{ Reoperation due to leak } & $\mathbf{n}$ & 1 & 0 & 1 & \\
\hline & & $\%$ & 100.0 & 0.0 & 100.0 & \\
\hline & \multirow{2}{*}{ Hypertrophic scar } & $\mathbf{n}$ & 5 & 2 & 7 & \\
\hline & & $\%$ & 71.4 & 28.6 & 100.0 & \\
\hline
\end{tabular}

Table 5 shows that the comparison between intra operative and post-operative complications in acute and chronic cholecystitis cases. Out of total complications, acute cholecystitis cases had higher number of complications in Intraoperatives well as in post-operative. Introperative complications such as intrahepatic gall bladder, cholecystodudenal fistula gall bladder perforation was more in chronic cholecystitis case however particularly mucocoele gall bladder was more frequent found in acute cholecystitis cases. None of the cases had Pericholecystic fluid collection and Perforated gall bladder complications. Postoperative complications such as skin infection, bile leak hypertrophic scar was more in acute cholecystitis case whereas no CBD injury and bowel injury were seen in both acute or chronic cholecystitis cases. One case was reoperated due to bile accumulation in acute cases due to accidental removal of drain. Difference among complications \& acute and chronic cholecystitis were not found statistically significant $(P>0.05)$.

\section{Discussion}

Open cholecystectomy is still prefered surgical approach for gall bladder stone in rural health centre of india but definitely laparascopic cholecystectomy in now increasing in india and has been treatment of choice in the world for gall 
stone disease ${ }^{[8]}$. In our studies we compared the effect of open cholecystectomy in acute and chronic gall stone disease in terms of operative time, intra and post-operative complications, hospital stay drain removal, operative cost, pain at discharge. open cholecystectomy is found to be superior treatment for chronic cholecystitis because of less time of operation, early drain removal, less hospital stay, low pain at discharge low cost, low intra and postoperative complications and earlier return to work without added morbidity. therfore open cholecystectomy for acute cholecystitis has not become routine procedure as most of the surgeon still wants to go first conservative approach then performed interval cholecystectomy, because the timing and approach to the surgical management in patients with acute cholecystitis is still a matter of controversy [9]. High complication rates have been reported by different studies for acute cholecystitis. Therefore, open cholecystectomy for chronic cholecystitis leads to technically easier surgery with a lower complictaion rate. In acute cases, mucocoele and edematous gall bladder, wall thickness, omental adhesion causing difficult surgery while in some cases of chronic cholecystitis open cholecystectomy was difficult due to contraction and and dense omental adhesions obscuring the anatomy of Calot's triangle.

in comparison of bile duct injury, None of the patients in either group had bile duct injury. 2 (1\%) patient had bile leak in drain the acute cases due to liver bed injury and both cases resolved spontaneously within one months.

Several technical key points must be kept in mind when open surgery is performed for acute cholecystitis. For good exposure of Calot's triangle, decompression for distended and edematous gallbladder should be done early because this allows better grasping and retraction of the gallbladder. In our study distended and edematous gall bladder was encountered in 16 cases out of which 13 (81.3\%) cases belong to acute cholecystitis. which posed a difficulty in grasping and retraction of the gall bladder and also obscured the Calot's triangle. Gallbladder decompression was even done in 3 $(18.7 \%)$ patients in the chronic group. A subhepatic drain was placed in all cases of both groups. Overall 2 cases had bile leak and were present in acute cholecystits due to difficult dissection of gallbladder from liver bed and drain was not removed at the time of discharge

Acute cholecystitis scored over chronic cholecystitis as far as operating time is concerned. The difference could be explained because of few reasons like encountering a distended and edematous gall bladder, which needed decompression, more vascularity around the gallbladder, and Calot's triangle and omental adhesions, which needed meticulous dissection.

The average blood loss was more in the acute group than in the chronic group; therefore drain removal was delayed in acute csases, however, no patient required blood transfusion in both group.

The total hospital stay in the acute cases group was significantly longer than the chronic group because of more post operative pain delayed drain removal higher drain output more operative time. Most studies published in international literature show a statistically significant difference in the total hospital stay.

Pain was more in case of acute cholecystitis than chronic cholecystitis because of longer operative time and dense adhesion also due to difficult dissection.

Operative cost was also singnificantly high in acute cases due to use of higher antibiotics and sometimes more than one analgesics drugs needed to control pain

\section{Conclusion}

In this study we found that Open cholecystectomy for acute case have significantly longer duration of operative time, longer duration of hospital stay, high cost of operation due to use of higher antibiotics, more pain complains, and high chances of biliary leak and skin infection. Therefore this study support 
that open cholecystectotomy should be avoid in acute cases and must be managed by conservative treatment. However, the findings need to be interpreted cautiously in light of small sample size,.to make more valid conclusions, future studies should include larger data to validate these findings.

\section{Declaration}

Research project has been approved by the ethical committee of navjeevan hospital kashipur uttrakhand.any question about ethical conduct of this research can be sent to same hospital address.

Competing interests

The authors declare that they have no competing interests.

\section{References}

[1]. Khuroo MS, Mahajan R, Zargar SA, Javid G, Sapru S (1989) Prevalence of biliary tract disease in India: a sonographic study in adult population in Kashmir. Gut 30: 201-205.

[2]. Traverso LW (1976) Carl Langenbuch and the first cholecystectomy. [Internet]. American journal of surgery $\mathrm{p}$ 81-82.

[3]. Oddsdottir M, Pharm TH. Gall bladder and the extra hepatic biliary system. In: Brunicardi FC, Andersen DK eds. Schwartz's principles of surgery. 9th edn. USA: McGraw-Hill Professional 2009:1151-1152.

[4]. Jani K, Rajan P S, Sendhilkumar K, Palanivelu C. Twenty years after Erich Muhe: Persisting controversies with the gold standard of laparoscopic cholecystectomy. J Min Access Surg 2006;2:49-58

[5]. Ros A, Gustafsson L, Krook H, Nordgren CE, Horell A, et al. (2001) Laparoscopic cholecystectomy vs. mini-laparotomy cholecystectomy. Ann Surg 234: 741-749

[6]. Manning RG, Aziz AQ (2009) Should laparoscopic cholecystectomy be practiced in the developing world? Ann Surg 249: 794-798

[7]. Paulino-Netto A (1993) A review of 391 selected open cholecystectomies for comparison with laparoscopic cholecystectomy. Am J Surg 166: 71-73.

[8]. Begos DG, Modlin IM. Laparoscopic cholecystectomy: from gimmick to gold standard. J Clin Gastroenterol. 1994 Dec;19(4):325-30. doi:
10.1097/00004836-199412000-00015. PMID: 7876516.

[9]. Yamashita Y, Takada T, Kawarada Y, Nimura Y, Hirota M, Miura F, et al. Surgical treatment of patients with acute cholecystitis: Tokyo Guidelines. J Hepatobiliary Pancreat Surg. 2007;14:91-7.

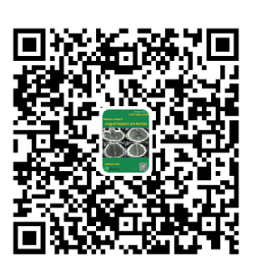

